\title{
KURIKULUM DAN PEMBELAJARAN MATEMATIKA DI JEPANG SERTA PERBANDINGANNYA DENGAN DI INDONESIA
}

\author{
Bety Miliyawati \\ betymiliyawati@gmail.com
}

\begin{abstract}
ABSTRAK
Kurikulum merupakan syarat mutlak bagi pendidikan di lembaga pendidikan. Kurikulum memiliki komponen-komponen yang saling berkaitan: tujuan, materi, metode, organisasi, dan evaluasi, sebagai dasar utama dalam upaya pengembangan sistem pembelajaran di lembaga pendidikan. Seperti halnya di Indonesia, pergantian kurikulum juga terjadi di Jepang, sekalipun tidak dalam frekuensi yang sama. Tujuan pembaharuan kurikulum Jepang adalah dengan harapan dapat memacu kreativitas para guru termasuk guru matematika dalam mengimplementasikan pengalaman belajar kepada peserta. Gakusyuushidouyouryou (kurikulum) Jepang, pertama kali dikeluarkan pada tahun 1947, bertepatan dengan lahirnya undang-undang pendidikan di Jepang, selanjutnya berkali-kali mengalami perubahan, yaitu pada tahun 1951, 1956, 1961, 1971, 1980, 1992, 2002, dan 2011. Panduan tentang muatan pembelajaran di sekolah termuat dalam Gakusyuushidouyouryou. Meskipun majunya pendidikan Jepang dan kemajuan industrinya benarbenar terwujud namun tetap sampai saat ini, pengembangan profesional guru dilakukan secara terus-menerus sebab Jepang menyadari karena miskin sumber daya alam maka pengembangan sumber daya manusia (termasuk guru) perlu dilakukan secara terus-menerus. Peningkatan mutu pendidikan, Jepang dimulai dengan peningkatan mutu pembelajaran di dalam kelas dan sistem pendidikan di sekolah. Sementara, para guru termasuk guru matematika di Jepang diharuskan memiliki kemampuan dalam melaksanakan pembelajaran, bukan sekedar melaksanakan pengajaran. Artikel ini mengkaji kurikulum dan pembelajaran matematika di Jepang serta perbandingannya dengan Indonesia, dengan tujuan dapat menjadi bahan refleksi dalam rangka berperan serta secara aktif dalam pengembangan kurikulum dan pembelajaran matematika di Indonesia.
\end{abstract}

Kata Kunci: kurikulum Jepang, pembelajaran matematika, perbandingan kurikulum.

\section{PENDAHULUAN}

Pendidikan memegang peranan penting dalam kehidupan manusia, sehingga itu mutlak didapatkan oleh setiap individu. Demikian pula kemajuan suatu bangsa dapat dilihat dari kualitas pendidikannya. Beberapa negara maju, seperti Jepang, Amerika, dan Singapura mempunyai kualitas pendidikan yang sangat bagus, jika dibandingkan dengan negara Indonesia yang begitu jauh ketinggalan kualitas pendidikannya. Salah satu faktor yang mempengaruhi bagusnya kualitas pendidikan di Jepang adalah kurikulum pendidikan di negara tersebut.

Kurikulum merupakan syarat mutlak bagi pendidikan di lembaga pendidikan. Sebagai syarat mutlak, berarti kurikulum merupakan bagian yang tidak terpisahkan dari 
pendidikan atau pengajaran. Arifin (2012) menyatakan kurikulum merupakan kumpulan mata-mata pelajaran yang digunakan sebagai pedoman penyelenggaraan kegiatan pembelajaran di lembaga pendidikan. Kurikulum Jepang memiliki karakteristik pengembangan yang berusaha menyesuaikan kondisi dan pemikiran. Sementara Ramli (2009) menyatakan bahwa konsep kurikulum di Jepang berkembang sejalan dengan perkembangan teori dan praktek pendidikan yang dianutnya.

Pembaharuan kurikulum Jepang menjadi tanggung-jawab pemerintah. Tetapi apa yang disusun oleh pemerintah hanyalah sebuah standar atau pembakuan yang selanjutnya merupakan acuan/pedoman dalam penyusunan kurikulum khas sekolah yang menjadi tanggung jawab kepala sekolah dan aparatnya. Pembaharuan kurikulum adalah hal yang mutlak terjadi, sebab pendidikan juga berjalan mengikuti zaman dan perubahan. Seperti halnya di Indonesia, pergantian kurikulum juga terjadi di Jepang, sekalipun tidak dalam frekuensi yang sama. Pangisyarwi (2015) mengungkapkan, pembaharuan kurikulum Jepang merupakan bagian dari strategi meningkatkan capaian mutu pendidikan. Sementara Ramli (2009) menyatakan, peningkatan mutu pendidikan di Jepang dimulai dengan peningkatan mutu pembelajaran di dalam kelas, sistem pendidikan di sekolah, dan bukan pada perubahan mata pelajaran atau metode mengajar.

Meskipun majunya pendidikan Jepang dan kemajuan industrinya benar-benar terwujud namun tetap sampai saat ini, pengembangan profesional guru dilakukan secara terus-menerus sebab Jepang menyadari karena miskin sumber daya alam maka pengembangan sumber daya manusia (termasuk guru) perlu dilakukan secara terusmenerus antara lain melalui sertifikasi guru dan uji kompetensi guru agar memenuhi kompetensi pedagogik, kepribadian sosial, dan profesional.

Kurikulum di Jepang sangat menarik dan menantang bagi peserta didik. Di dalam kurikulum di Jepang, yang terpenting adalah bukan banyaknya materi pelajaran, namun yang terpenting adalah pendekatan cara mendidiknya. Hal ini sangat berbeda sekali dengan kurikulum di Indonesia yang padat akan materi, sehingga terkadang peserta didik menjadi kewalahan dalam mempelajarinya. Ramli (2009) menyatakan, permasalahan kurikulum bukan terletak pada perubahan isi setiap mata pelajaran, atau bukan pada perubahan metode pengajaran di kelas, tetapi harus memuat sistem pendidikan di kelas.

Kurikulum Jepang pertama kali dikeluarkan pada tahun 1947, bertepatan dengan lahirnya undang-undang pendidikan di Jepang, selanjutnya berkali-kali mengalami perubahan, yaitu pada tahun 1951, 1956, 1961, 1971, 1980, 1992, 2002, dan 2011. 
Perubahan tersebut membawa dampak perubahan permintaan kualifikasi dan kompetensi pendidik di Jepang. Salah satu tujuan perubahan kurikulum Jepang adalah dengan harapan dapat memacu kreativitas para guru bidang studi termasuk guru matematika dalam merancang dan mengimplementasikan pengalaman belajar kepada peserta didik di kelas, di samping menjadikan lulusannya sebagai "agent of change”. baik di lingkungan sekolah, di lingkungan masyarakat maupun ketika melanjutkan kuliah. Tugas utama guru matematika adalah membelajarkan siswa materi dan kegiatan matematika bukan mengajarkan. Guru matematika di Jepang harus memiliki kemampuan dalam melaksanakan pembelajaran, bukan sekedar melaksanakan pengajaran.

Kerangka kurikulum Jepang untuk bidang studi matematika tidak ditargetkan untuk menguasai luasnya cakupan, tetapi justru menargetkan kedalaman proses pembelajarannya (Schmidt, McKnight, \& Raizen, 1996, dalam Tanti, 2012).. Pembelajaran matematika di Jepang berdasarkan masalah kontekstual. Peserta didik diberikan kebebasan pola pikir dalam menyelesaikan masalah, artinya guru memberikan sebuah permasalahan berkaitan dengan kehidupan sehari-hari untuk dipecahkan sesuai dengan pola pikirnya peserta didik. $\mathrm{Hal}$ ini sangat berbeda dengan pembelajaran matematika di Indonesia yang bersifat abstrak dan hafalan. Prosedur yang dilakukan oleh guru adalah meminta siswa mendengarkan apa yang dijelaskan guru kemudian siswa diperintahkan untuk aktif mengerjakan soal-soal latihan yang diambil dari buku. Hal ini dilakukan secara terus-menerus oleh individu seorang guru matematika. Kemudian pembelajaran berakhir dengan tersusun secara rapi, dan pembelajaran berikutnya akan berlangsung dengan aktivitas yang serupa. Bertolak dari uraian di atas, maka untuk mengatasi hal ini, penulis mencoba menganalisis lebih jauh bagaimana pengembangan kurikulum dan pembelajaran matematika yang berlangsung di Jepang serta perbandingannya dengan di Indonesia, dengan harapan dapat menjadi bahan renungan dalam rangka berperan serta secara aktif dalam pengembangan kurikulum dan pembelajaran matematika yang berlangsung di Indonesia.

\section{PEMBAHASAN}

\section{Kurikulum}

Kurikulum merupakan alat untuk mencapai tujuan pendidikan, sekaligus sebagai pedoman dalam melaksanakan pendidikan dan pengajaran. Kurikulum mencerminkan falsafah hidup bangsa, ke arah mana dan bagaimana bentuk kehidupan itu kelak di tentukan oleh kurikulum yang di gunakan oleh bangsa tersebut. Arifin (2012) mengatakan 
kurikulum sebagai seperangkat mata pelajaran atau materinya yang akan dipelajari, atau yang akan diajarkan guru kepada peserta didik. Bagi kebanyakan peserta didik, kurikulum identik dengan tugas pelajaran, latihan atau isi buku pelajaran. Bagi guru, kurikulum seringkali diasosiasikan dengan petunjuk atau pedoman tentang konten kurikulum (materi pelajaran) yang akan diajarkan kepada peserta didik di samping strategi, metode atau teknik mengajar serta buku sumber materi ajar (Brady \& Kennedy, 2007). Sementara Hamalik (2001), menyatakan kurikulum dapat dianggap sebagai suatu jembatan yang penting, untuk mencapai suatu titik akhir perjalanan, yang ditandai dengan perolehan ijazah.

Lebih jauh, Djauhari (2010) mengatakan kurikulum adalah semua pengalaman perserta didik yang dirancang, diarahkan, diberikan, dan dipertanggungjawabkan oleh lembaga pendidikan. Pengalaman peserta didik harus disajikan dalam proses pembelajaran yang tepat, yang harus diterapkan baik untuk pengembangan profil keilmuannya, maupun untuk mengembangkan profil keprofesian dan profil sosial, serta didukung oleh lembaga pendidikan yang kondusif (Rini, 2014). Di lain pihak, Sukmadinata (1997) menyatakan kurikulum sebagai suatu sistem keseluruhan memiliki komponen-komponen yang saling berkaitan: tujuan, materi, metode, organisasi, dan evaluasi. Komponen-komponen ini menjadi dasar utama dalam upaya pengembangan sistem pembelajaran di lembaga pendidikan. Para administrator seperti pimpinan institusi, pejabat struktural di bidang pendidikan, para pakar pendidikan, para pengajar, bahkan orang tua siswa sendiri, tidak hanya terlibat secara langsung atau tidak langsung dalam proses pengembangan kurikulum, tetapi juga seharusnya turut aktif dalam implementasi suatu kurikulum.

Berdasarkan definisi-definisi kurikulum yang telah di uraikan di atas, dapat disimpulkan bahwa kurikulum merupakan syarat mutlak bagi pendidikan di lembaga pendidikan. Sebagai syarat mutlak, berarti kurikulum merupakan bagian yang tidak terpisahkan dari pendidikan atau proses pembelajaran. Komponen materi dan kegiatan belajar peserta didik harus ada pada proses pembelajaran. Hal ini penting mengingat pembelajaran tanpa keterlibatan aktif peserta didik mempelajari konten atau materi, itu berarti hanya sekedar informasi bagi peserta didik, belum menjadi pengetahuan atau pengalaman belajar apalagi kompetensi siswa. 


\section{Kurikulum Pendidikan Jepang}

Bangsa Jepang, walaupun sudah maju diberbagai bidang kehidupan termasuk di bidang pendidikan tetapi dalam rangka mempersiapkan diri secara lebih baik lagi, maka pengembangan kurikulum terus ditingkatkan demi kemajuan-kemajuan kualitas pendidikan di negara Jepang itu sendiri. Kurikulum di Jepang disusun oleh bagian perencanaan kurikulum yang terdapat dalam Kementrian Pendidikan (MEXT, 2006). Penyusunan kurikulum Jepang lebih ditekankan pada sistem pendidikan di sekolah, bukan pada perubahan mata pelajaran atau metode mengajar. Sifatnya fleksibel dan responsif dalam konteks penerapan kurikulumnya memungkinkan para pendidik untuk melakukan pengembangan dan penyesuaian-penyesuaian pada tataran implementatif di dalam kelas. Menurut Chibi, A. (2014), kurikulum Jepang, pertama kali dikeluarkan pada tahun 1947, bertepatan dengan lahirnya UU pendidikan di Jepang, selanjutnya berkali-kali mengalami perubahan, yaitu pada tahun 1951, 1956, 1961, 1971, 1980, 1992, 2002, dan 2011. Hal-hal yang ditegaskan oleh Kementerian Pendidikan Jepang terkait dengan menyusun kurikulum adalah: 1) standar kurikulum nasional, 2) mengutamakan keharmonisan pertumbuhan jasmani dan rohani siswa, 3) menyesuaikan dengan lingkungan sekitar, 4) memperhatikan step perkembangan siswa, dan 5) memperhatikan karakteristik course pendidikan/jurusan pada level SMA.

Panduan kurikulum Jepang disebut Gakushū Shidōyōryō (GS) yang diakui secara hukum, sehingga pelanggaran terhadapnya akan dikenai sanksi hukum. GS merupakan panduan kurikulum untuk SD (shōgakkō), SMP (chūgakkō), SMP-SMA satu atap (chūtōkyōikugakkō), SMA (kōtōgakkō), dan SLB (tokubetsushiengakkō). Sedangkan untuk panduan kurikulum Taman Kanak-Kanak (yōchien) disebut yōchienkyouikuyōryō. Untuk penyusunan dan publikasi kurikulum dilakukan tiga tahun sebelum diterapkan. Misalnya untuk reformasi kurikulum SMP yang direncanakan akan diterapkan pada tahun 2012, telah terselesaikan penyusunannya sekaligus diumumkan ke publik pada bulan Maret 2011 untuk mendapatkan masukan. Reformasi kurikulum ini dengan tujuan memacu kreativitas para guru termasuk guru bidang studi termasuk guru matematika dalam merancang dan mengimplementasikan pengalaman belajar bagi para peserta didik di kelas. Pengembangan profesional guru dilakukan secara terus-menerus sebab Jepang menyadari karena miskin sumber daya alam maka pengembangan sumber daya manusia (termasuk guru), dilakukan secara terus-menerus. 
Karakteristik kurikulum SD di Jepang hampir sama dengan kurikulum SD di Indonesia. Kurikulum SD di Jepang meliputi bahasa Jepang, ilmu sosial, matematika, ilmu pengetahuan, pendidikan moral, musik, seni dan kerajinan, kerumahtanggaan, dan pendidikan jasmani. Perbedaannya dengan kurikulum SD di Indonesia terlihat pada mata pelajaran seikatsuka (kebiasaan hidup) yang diajarkan di kelas 1 dan 2 SD. Mapel ini bertujuan untuk membiasakan anak-anak dengan cara hidup mandiri sehari-hari kepada anak-anak yang baru menyelesaikan pembelajaran di TK. Pembelajaran bahasa Jepang dan berhitung diajarkan lebih banyak dibandingkan pelajaran lainnya. Sedangkan sekolahsekolah agama lebih banyak mengajarkan pendidikan agama (Kristen, Buddha, Sinto) sebagai bagian dari pendidikan moral. Selain itu, pendidikan estetika berupa musik dan menggambar juga diajarkan dalam porsi besar di kelas 1 dan 2 Sekolah Dasar.

Untuk kurikulum SMP meliputi bahasa Jepang, matematika, ilmu sosial, ilmu pengetahuan, bahasa Inggris, musik, seni, pendidikan jasmani, pendidikan moral, dan klub ekskul. Pelajaran bahasa asing diajarkan dalam bentuk mapel pilihan, di antaranya bahasa Inggris, bahasa Perancis, dan bahasa Jerman. Semua mata pelajaran dialokasikan waktu pembelajaran integrated course diberikan lebih besar (90 jam) dibandingkan dengan mapel di SD. Mata pelajaran bahasa Inggris dijadikan mapel wajib SMP. Sementara mata pelajaran pilihan yaitu bahasa Jepang, IPS, Matematika, IPA, Musik, pendidikan jasmani dan kesehatan, keterampilan/Homemaking. Dan bahasa Asing, merupakan perbedaan khas antara kurikulum SMP di Indonesia dan Jepang.

Selanjutnya, karakteristik kurikulum SMA di Jepang paling sering berubah-ubah. Perubahan tampak pada nomenklatur mata pelajaran, kategorisasi, dan sistem penjurusan. Sifat khas kurikulum SMA adalah kompleksnya mapel yang diajarkan. Pelajaran bahasa Jepang dikelompokkan lebih detil menjadi pendidikan bahasa Jepang, literature klasik dan literature modern. Untuk kurikulum bahasa Asing, Jepang memperkenalkan bahasa Inggris, bahasa Jerman, dan bahasa Perancis. Sementara, penjurusan dilakukan sejak kelas 3 SMA, dan jurusan yang ada pada dasarnya adalah jurusan rika (IPA) dan bunka (budaya/sosial). Penjurusan dikembangkan dengan melihat nilai mata pelajaran, yang ada hubungannya dengan jurusan teknik, pertanian, perikanan, kesejahteraan masyarakat, sesuai kebutuhan lapangan. Selain itu, sekolah juga membagi lebih detil penjurusan menjadi Jurusan yang dipersiapkan untuk menghadapi ujian masuk universitas negeri dan Jurusan yang memilih universitas swasta. 
Lebih jauh, pendidikan dasar di Jepang dilengkapi dengan tokubetsukatsudou, sebagai aktivitas khusus atau semacam ekstra kurikuler di Indonesia, tetapi agak berbeda karena kegiatan ini meliputi OSIS, kegiatan kelas, kegiatan klub olahraga dan seni, event sekolah dan pendidikan moral. Event sekolah seperti festival sekolah (gakkousai) dipersiapkan per kelas dengan bimbingan penuh dari wali kelas. Jumlah jam pelajaran di SMP sebanyak 385 jam, hal ini dimaksudkan memberikan waktu dan ruang kepada guru dalam melaksanakan Yutorikyouiku. Yutorikyouiku dalam kaitannya dengan sistem pendidikan di Jepang dapat meningkatkan kedisiplinan siswa dalam belajar. Chibi, A. (2014) menyatakan bahwa pelaksanaan Yutorikyouiku, pemerintah menerapkan 5 hari sekolah, yaitu dari hari Senin sampai Jumat. Tujuan kebijakan ini adalah agar siswa dapat lebih banyak memanfaatkan waktunya dengan keluarga dan belajar lebih banyak di lingkungannya dan atau mengikuti berbagai les privat.

\section{Kurikulum Pendidikan Matematika di Jepang}

Kurikulum yang dikembangkan untuk mahasiswa Program Studi Strata Satu Pendidikan Matematika di Jepang, dikembangkan atas dasar filosofi dengan bergantungan pada 5 (lima) komponen yang saling terkait. Kelima komponen tersebut sebagaimana dapat digambarkan dalam sebuah segilima sebagai berikut.

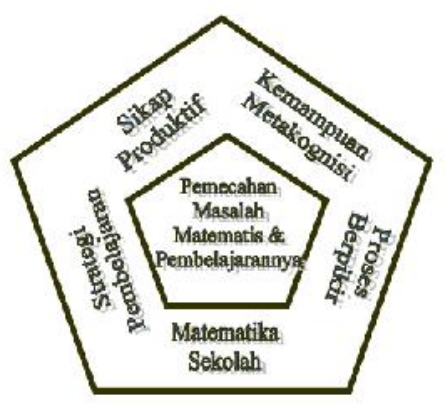

Gambar 1. Komponen Kurikulum Pendidikan Matematika Jepang

Filosofi ini dikembangkan oleh para pakar pendidikan matematika di Jepang, dengan tujuan agar lulusan memiliki kemampuan pemecahan masalah matematis maupun pembelajarannya. Mahasiswa lebih banyak dibekali materi tentang: (1) Matematika Sekolah, (2) Strategi Pembelajaran Matematika, (3) Proses Berpikir Matematis, (4) Kemampuan Metakognisi, dan (5) Sikap Produktif. Disamping itu, ada tiga hal lain yang ditekankan kepada mahasiswa, diantaranya: penguasaan akan proses berpikir matematis, kemampuan melakukan metakognisi, dan sikap yang produktif (Tanti, 2012). 
Mengapa ketiga hal ini perlu ditekankan kepada mahasiswa? NIER (1999) berpendapat bahwa dengan proses berpikir matematis yang baik, mahasiswa akan senantiasa dapat menempatkan setiap permasalahan dalam koridor yang tepat. Mahasiswa bisa mengklasifikasikan, membandingkan, mengurutkan, menganalisis bagian dan keseluruhan, mengidentifikasi pola yang ada. Mahasiswa juga memiliki berbagai macam strategi heuristik pemecahan masalah yang memungkinkan mereka mampu menyederhanakan masalah dan membuat langkah penyelesaian yang tepat.

Selanjutnya, dengan kemampuan metakognisi yang ada, mahasiswa bisa menengok ulang proses dan alur berpikir yang dilaluinya ketika dia berusaha memecahkan masalah. Dengan begitu dia akan dapat melakukan refleksi diri dan menemukan kelemahankelemahan serta potensi perbaikannya. Ini akan sangat bermanfaat mereka untuk senantiasa melakukan perbaikan dari hari ke hari. Dengan sikap yang produktif, mahasiswa akan terus tertantang dan senantiasa melakukan banyak hal positif. Mahasiswa tidak akan mudah menyerah setiap kali berhadapan dengan masalah. Mahasiswa akan tidak pernah puas dengan prestasi yang dicapai. Mahasiswa akan selalu aktif dan kreatif memecahkan masalah terkait dengan perkuliahan sehingga mencapai hasil belajar yang optimal.

\section{Pembelajaran Matematika Di Indonesia dan Di Jepang}

Pembelajaran merupakan suatu proses aktif yang dilakukan oleh guru sebagai usaha untuk mengembangkan segala potensi yang terdapat dalam diri peserta didik. Menurut Suherman dkk, (2003), "Pembelajaran merupakan upaya penataan lingkungan yang memberi nuansa agar program belajar tumbuh dan berkembang secara optimal. Dari pengertian ini dapat kita ketahui bahwa pembelajaran merupakan suatu proses sistematik yang sengaja dibuat oleh pendidik guna menciptakan suatu kondisi yang baik bagi peserta didik dalam proses pembelajaran. Untuk melaksanakan proses pembelajaran yang baik, guru dapat menyusun suatu skenario pembelajaran yang harus disesuaikan dengan materi yang diberikan, situasi dan kondisi kelas yang dihadapi berpedoman kepada langkahlangkah yang telah ditetapkan sebelumnya.

Mengapa perlunya sekolah mengajarkan matematika kepada peserta didik. Cockroft (Mulyono, 2003), mengemukakan bahwa matematika perlu diajarkan kepada peserta didik karena a) selalu digunakan dalam segala segi kehidupan; b) semua bidang studi memerlukan keterampilan matematika yang sesuai; c) merupakan sarana komunikasi yang kuat, singkat, dan jelas; d) dapat digunakan untuk menyajikan informasi dalam 
berbagai cara; e) meningkatkan kemampuan berpikir logis, ketelitian, dan kesadaran keruangan; dan f) memberikan kepuasan terhadap usaha memecahkan masalah yang menantang. Di sisi lain, Hudojo (2005) menyatakan matematika pada hakikatnya merupakan suatu pengetahuan yang disusun secara konsisten berdasarkan logika deduktif. Menurut akal sehat sehari-hari, kebenaran matematika tidak ditentukan oleh pembuktian secara empiris, melainkan pada proses penalaran deduktif. Sementara, Kline (dalam Mulyono, 2003), menjelaskan bahwa "matematika merupakan bahasa simbolis dan ciri utamanya adalah penggunaan cara bernalar deduktif, tetapi juga tidak melupakan cara bernalar induktif."

Nikson (Muliyardi, 2006), mengemukakan bahwa "pembelajaran matematika adalah suatu upaya membantu peserta didik untuk menkonstruksi (membangun) konsep-konsep dan prinsip-prinsip matematika dengan kemampuannya sendiri melalui proses internalisasi sehingga konsep atau prinsip itu terbangun kembali”. Seorang peserta didik tertarik untuk mempelajari sesuatu jika dia dapat melihat bahwa sesuatu yang dipelajari itu dapat berguna baginya. Untuk itu pembelajaran matematika harus bermakna, artinya peserta didik melihat bahwa matematika penting untuk dirinya kelak karena dapat membantunya memecahkan masalah-masalah yang dihadapi.

Kenyataannya, prototipe pembelajaran matematika di Indonesia kira-kira sejalan dengan yang diungkapkan oleh de Lange (1996) bahwa pembelajaran matematika seringkali ditafsirkan sebagai kegiatan yang dilaksanakan guru, ia mengenalkan subjek, memberikan satu atau dua contoh, lalu ia mungkin menanyakan satu atau dua pertanyaan, dan pada umumnya meminta siswa yang biasanya mendengarkan secara pasif untuk menjadi aktif dengan memulai mengerjakan latihan yang diambil dari buku. Hal ini dilakukan secara terus-menerus oleh individu seorang guru. Kemudian pembelajaran berakhir dengan tersusun secara rapi, dan pembelajaran berikutnya akan berlangsung dengan aktivitas yang serupa. Di pihak lain, mantan Menteri Pendidikan dan Kebudayaan kita, Djojonegoro (1995) dalam sebuah seminar nasional pernah mengungkapkan bahwa kebanyakan sekolah dan guru-guru di Indonesia memperlakukan siswa bagaikan suatu wadah yang siap untuk di isi pengetahuan. Begitulah ilustrasi pembelajaran matematika yang pada umumnya sedang berlangsung di Indonesia.

Hal hal seperti disampaikan di atas, relevan dengan apa yang dikemukakan oleh Silver (dalam Turmudi, 2008) bahwa pada umumnya dalam pembelajaran matematika, para siswa menonton bagaimana gurunya mendemonstrasikan penyelesaian soal-soal 
matematika di papan tulis dan siswa mengkopi apa yang telah dituliskan oleh gurunya. Hal serupa juga dikemukakan oleh Senk \& Thompson (2003) bahwa dalam kelas tradisional, umumnya guru-guru menjelaskan pembelajaran matematika dengan mengungkapkan rumus-rumus dan dalil-dalil matematika terlebih dahulu, baru siswa berlatih dengan soalsoal yang disediakan.

Dengan memperhatikan apa yang dikatakan oleh para ahli pendidikan matematika di atas dapatlah dikatakan bahwa situasi di Indonesia saat ini khususnya dalam pembelajaran matematika masih menganut sistem pembelajaran tradisional (Jihad, 2008). Oleh karena itu, untuk mengatasi hal ini, ada pemikiran penulis untuk meniru pembelajaran di Jepang. Sebagaimana dikemukakan oleh Stigler \& Stevenson (1991) bahwa jika kita mempertanyakan secara singkat bagaimana karakteristik kelas matematika di Jepang akan dikatakan bahwa pembelajaran itu akan terdiri atas pelajaran yang berkaitan secara logis disajikan secara bijaksana, rileks, dan dengan cara yang non-otoritatif. Pembelajaran matematika di Jepang berorientasi pada pemecahan masalah dan menggunakan banyak bentuk representasi materi pelajaran yang beragam. Peranan yang diasumsikan guru adalah pengetahuan yang dapat dibimbingkan, bukan hanya menyediakan informasi dan memeriksa apa yang benar dari siswa. Guru tidak terlalu banyak menghabiskan waktunya hanya dengan ceramah, melainkan mencoba membimbing siswa untuk diskusi dan intraksi secara produktif.

Peran guru di Jepang sama halnya di Indonesia yaitu sebagai fasilitator hanya saja di Jepang menganut tiga prisip mengajar untuk guru yaitu Tanoshii jogyou (kelas harus menyenangkan), Wakaru ko (anak harus mengerti), Dekiru ko (anak harus bisa). Untuk metode pembelajaran yang digunakan di Jepang yaitu dengan tutor sebaya (peer learning) atau yang disebut lesson study. Pembelajaran matematika di Jepang menggunakan metode open-ended, problem solving, dan kontekstual. Secara umum pembelajaran matematika yang berlangsung di Jepang, sebagaimana dicatat oleh Stevenson \& Nerison-Low (2002) bahwa struktur pembelajaran matematika di Jepang penekanannya pada penyajian permasalahan praktis, menjelaskan perbedaan-perbedaan solusi yang diberikan siswa, meminta siswa lain mengomentari dan mengevaluasi efektivitas penyelesaian siswa, kemudian membawa pelajaran matematika kepada suatu ringkasan dan penutup dengan menyatakan aturan yang mendasari penyelesaian persoalan matematika yang disajikan. Umumnya persoalan matematika yang disajikan kepada siswa merupakan soal-soal yang bersifat problem solving. 
Meskipun pembelajaran matematika di negara kita belum memperlihatkan pembelajaran matematika sebagaimana diungkapkan Stigler \& Stevenson (1991) di atas namun paling tidak dapat ditiru dan dijadikan contoh dilaksanakan oleh guru-guru kita di Indonesia. Leder (1992) menyatakan bahwa akhir-akhir ini ada hal menarik perhatian yaitu sedikit perhatian kepada paham bahwa "paling baik guru membantu siswanya belajar matematika adalah dengan cara dengan menggunakan urutan tertentu dan melalui prosedur tertentu untuk disajikan kepada siswa" dan menurut Leder bahwa "belajar adalah hasil dari konstruksi aktif siswa tentang matematika dengan caranya yang unik karena mereka berinteraksi dengan lingkungannya, melewati proses-proses pengalaman berbeda dan membangun pengetahuan yang telah mereka miliki”. Hal ini akan mendatangkan suatu cara mengajar yang mengaktifkan siswa membangun pengetahuan matematika secara mandiri. Permasalahannya adalah bagaimana kesiapan guru memfasilitasi aktivitas matematika siswa sedemikian sehingga tercipta situasi yang kondusif untuk terwujudnya "masyarakat sekolah" yang gandrung terhadap matematika.

\section{Perbandingan Kurikulum Pendidikan di Jepang dan di Indonesia}

Dengan memperhatikan kurikulum pendidikan di Jepang tersebut, dapatlah kiranya dibuat suatu perbandingan kurikulum pendidikan di Jepang dengan di Indonesia sebagaimana disajikan dalam tabel berikut.

Tabel 1. Perbandingan Kurikulum

\begin{tabular}{|c|c|c|c|}
\hline No & $\begin{array}{l}\text { Unsur/komponen } \\
\text { yang di cermati }\end{array}$ & Gakusyuushidouyouryou Jepang & Kurnas di Indonesia \\
\hline 1. & $\begin{array}{l}\text { Karakteristik } \\
\text { Kurikulum }\end{array}$ & 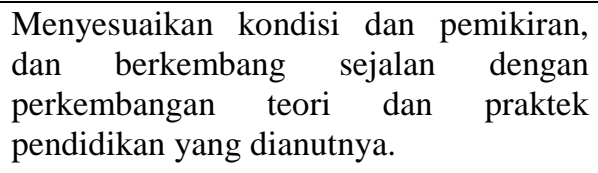 & $\begin{array}{l}\text { Berkembang sejalan dengan } \\
\text { perkembangan teori dan praktek } \\
\text { di lapangan }\end{array}$ \\
\hline 2. & $\begin{array}{l}\text { Program pendidikan } \\
\text { pada Junior College } \\
\text { (Akademik) }\end{array}$ & $\begin{array}{l}\text { Kurikulumnya tunggal, misalnya musik } \\
\text { saja, melukis saja, atau sastra Inggris. } \\
\text { Kebanyakan untuk wanita, dengan tujuan } \\
\text { untuk meningkatkan kemampuan wanita } \\
\text { sebagai ibu rumah tangga. }\end{array}$ & $\begin{array}{l}\text { Kurikulumnya satu disiplin ilmu, } \\
\text { terutama ilmu terapan, misalnya } \\
\text { akademi ilmu ekonomi. } \\
\text { Tujuanya lebih diarahkan untuk } \\
\text { menjadi tenaga terampil yang } \\
\text { siap kerja. }\end{array}$ \\
\hline 3. & $\begin{array}{l}\text { Pengembangan } \\
\text { Kurikulum Sekolah }\end{array}$ & $\begin{array}{l}\text { Lebih menekankan pada sistem } \\
\text { pendidikan di sekolah, bukan pada } \\
\text { perubahan mata pelajaran atau metode } \\
\text { mengajar. } \\
\text { Gakusyuushidouyouryou (kurikulum) } \\
\text { pertama kali dikeluarkan pada tahun } \\
\text { 1947, bertepatan dengan lahirnya UU } \\
\text { Pendidikan di Jepang. Selanjutnya } \\
\text { berkali-kali mengalami pembaharuan } \\
\text { yaitu pada tahun 1951, 1956, 1961, 1971, } \\
\text { 1980,1992, 2002, dan 2011. }\end{array}$ & $\begin{array}{l}\text { Tampaknya masih bertumpu } \\
\text { pada mata pelajaran, belum pada } \\
\text { sistem pendidikannya. } \\
\text { Dimualai dari Rencana Pelajaran } \\
1947,1952,1964, \text { kurikulum } \\
\text { 1968, 1975, 1984, 1988, 1994, } \\
\text { Suplemen 1999, } 2004 \text { (KBK), } \\
2006 \text { (KTSP), 2013 (Kurikulum } \\
\text { Nasional). }\end{array}$ \\
\hline
\end{tabular}




\begin{tabular}{|c|c|c|c|}
\hline 4. & Kurikulum SD & $\begin{array}{l}\text { Meliputi bahasa Jepang, ilmu sosial, } \\
\text { matematika, ilmu pengetahuan, } \\
\text { pendidikan moral, musik, seni dan } \\
\text { kerajinan, kerumahtanggaan, dan } \\
\text { pendidikan jasmani. Pembelajaran } \\
\text { bahasa Jepang dan berhitung diajarkan } \\
\text { lebih banyak dibandingkan pelajaran } \\
\text { lainnya. }\end{array}$ & $\begin{array}{l}\text { Perbedaannya pada mata } \\
\text { pelajaran seikatsuka (kebiasaan } \\
\text { hidup) yang diajarkan di kelas } 1 \\
\text { \& } 2 \text { Sekolah Dasar. Alokasi } \\
\text { waktu pembelajaran bahasa } \\
\text { daerah dan berhitung lebih } \\
\text { sedikit dibandingkan mata } \\
\text { pelajaran lainnya. }\end{array}$ \\
\hline 5. & Kurikulum SMP & $\begin{array}{l}\text { Meliputi bahasa Jepang, matematika, } \\
\text { ilmu sosial, ilmu pengetahuan, musik, } \\
\text { seni, pendidikan jasmani, pendidikan } \\
\text { moral, dan klub ekskul. Sedangkan } \\
\text { mapel pilihan, di antaranya bahasa } \\
\text { Inggris, bahasa Perancis, dan bahasa } \\
\text { Jerman. }\end{array}$ & $\begin{array}{l}\text { Perbedaan pada khas bahasa } \\
\text { Asing, dimana mata pelajaran } \\
\text { bahasa Inggris Indonesia sebagai } \\
\text { mata pelajaran wajib. }\end{array}$ \\
\hline 6. & Kurikulum SMA & $\begin{array}{l}\text { Sering berubah-ubah, pada nomenklatur } \\
\text { mata pelajaran dan kategorisasi. } \\
\text { Pelajaran bahasa Jepang dikelompokkan } \\
\text { lebih detil menjadi pendidikan bahasa } \\
\text { Jepang, literature klasik dan literature } \\
\text { modern. Untuk bahasa Asing, Jepang } \\
\text { memperkenalkan bahasa Inggris, bahasa } \\
\text { Jerman, dan bahasa Perancis. Sementara, } \\
\text { penjurusan dilakukan sejak kelas } 3 \text { SMA. }\end{array}$ & $\begin{array}{l}\text { Mata pelajaran yang ditetapkan } \\
\text { tidak berubah-ubah. Perbedaan } \\
\text { pada khas bahasa Asing, dimana } \\
\text { mata pelajaran bahasa Inggris } \\
\text { Indonesia sebagai mata pelajaran } \\
\text { wajib. Penjurusan dilakukan } \\
\text { sejak kelas } 2 \text { SMA. }\end{array}$ \\
\hline 7. & Hari efektif belajar & 5 hari (Senin s.d Jumat & 6 hari (Senin s.d Sabtu) \\
\hline 8. & $\begin{array}{l}\text { Kemunduran } \\
\text { Pendidikan }\end{array}$ & $\begin{array}{l}\text { Kemunduran pendidikan di Jepang } \\
\text { ditandai antara lain: menurunnya minat } \\
\text { bersekolah anak-anak, kedisplinan yang } \\
\text { mulai rapuh, dan prestasi belajar yang } \\
\text { menurun. }\end{array}$ & $\begin{array}{l}\text { Pelaksanaan pendidikan di } \\
\text { Indonesia lebih longgar, tidak } \\
\text { seketat Jepang, namun tanda- } \\
\text { tanda kemunduran pendidikan di } \\
\text { Jepang tampaknya juga terjadi } \\
\text { Indonesia. }\end{array}$ \\
\hline 9. & $\begin{array}{l}\text { Pengembangan } \\
\text { profesionalisme Guru }\end{array}$ & $\begin{array}{l}\text { Dilakukan secara terus menerus. Jepang } \\
\text { menyadari karena miskin sumber daya } \\
\text { alam maka pengembangan sumber daya } \\
\text { manusia (termasuk guru) perlu dilakukan } \\
\text { terus menerus. }\end{array}$ & $\begin{array}{l}\text { Dilakukan secara terus menerus, } \\
\text { antara lain melalui Sertifikasi } \\
\text { Guru dan Uji Kompetensi Guru } \\
\text { agar memenuhi kompetensi } \\
\text { pedagogik, kepribadian sosial, } \\
\text { dan profesional. }\end{array}$ \\
\hline 10 & $\begin{array}{l}\text { Peningkatan } \\
\text { pendidikan }\end{array}$ & $\begin{array}{l}\text { Dimulai dengan peningkatan mutu } \\
\text { pembelajaran di dalam kelas, sistem } \\
\text { pendidikan di sekolah, dan bukan pada } \\
\text { perubahan mata pelajaran atau metode } \\
\text { mengajar. }\end{array}$ & $\begin{array}{l}\text { Peningkatan mutu pendidikan } \\
\text { dilihat dari sistem pendidikan } \\
\text { dan hasil ujian Nasional di } \\
\text { sekolah. }\end{array}$ \\
\hline 11. & Prinsip Mengajar & $\begin{array}{l}\text { Ada tiga prisip mengajar yaitu Tanoshii } \\
\text { jogyou (kelas harus menyenangkan), } \\
\text { Wakaru ko (anak harus mengerti), } \\
\text { Dekiru ko (anak harus bisa). }\end{array}$ & 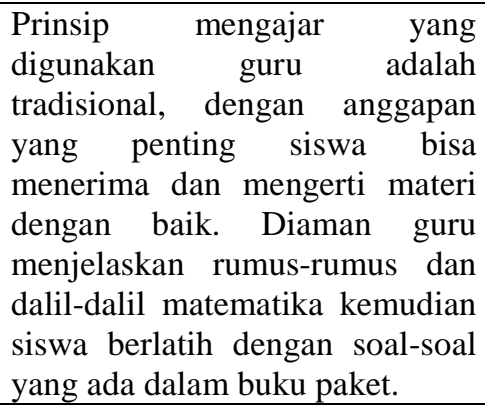 \\
\hline 12. & Metode Pembelajaran & $\begin{array}{l}\text { Dengan menerapkan metode tutor sebaya } \\
\text { (Peer learning) atau yang disebut Lesson }\end{array}$ & $\begin{array}{l}\text { Guru sebagai fasilitator, dan } \\
\text { menganut sistem pembelajaran }\end{array}$ \\
\hline
\end{tabular}




\begin{tabular}{|c|c|c|c|}
\hline & & $\begin{array}{l}\text { Study, pendekatan open-ended, problem } \\
\text { solving, dan kontekstual. }\end{array}$ & tradisional \\
\hline 13. & $\begin{array}{l}\text { Struktur pembelajaran } \\
\text { matematika }\end{array}$ & $\begin{array}{l}\text { Pada umumnya persoalan yang disajikan } \\
\text { kepada siswa merupakan soal-soal yang } \\
\text { bersifat problem solving, dan atau } \\
\text { menggunakan bentuk representasi materi } \\
\text { pelajaran yang beragam. }\end{array}$ & $\begin{array}{l}\text { Pada umumnya, } \\
\text { menonton biswa } \\
\text { mendemonstrasikan } \\
\text { penyelesaian soal-soal di papan } \\
\text { tulis dan siswa mengkopi apa } \\
\text { yang telah dituliskan oleh } \\
\text { gurunya. Dan pada umumnya } \\
\text { guru menjelaskan matematika } \\
\text { dengan mengungkapkan rumus- } \\
\text { rumus dan dalil-dalil terlebih } \\
\text { dahulu, baru siswa berlatih } \\
\text { dengan soal-soal yang tersedia } \\
\text { dalam buku paket. }\end{array}$ \\
\hline 14 & $\begin{array}{l}\text { Pelaksanaan } \\
\text { Nasional }\end{array}$ & Tidak ada pelaksanaan Ujian Nasional & $\begin{array}{l}\text { Pelaksanaan } \\
\text { (UN) }\end{array}$ \\
\hline
\end{tabular}

\section{KESIMPULAN}

Berdasarkan pembahasan tentang kurikulum dan pembelajaran matematika di Jepang serta perbandingannya dengan di Indonesia, maka dapat disimpulkan bahwa: Kurikulum Jepang memiliki karakteristik pengembangan yang berusaha menyesuaikan kondisi dan pemikiran masyarakat Jepang. Perubahan tersebut juga mengikuti perkembangan yang terjadi di dunia internasional. Sedangkan pengembangan kurikulumnya lebih menekankan pada sistem pendidikan di sekolah, bukan pada perubahan mata pelajaran atau metode mengajar. Sementara pengembangan kurikulum pendidikan matematika di Jepang dikembangkan atas dasar filosofi, sedangkan pembelajaran matematika dilaksanakan sesuai teori-teori pembelajaran matematika terkini dan bergantung pada 5 (lima) komponen yang saling terkait. Kelima komponen tersebut, yaitu konsep (concept), keterampilan (skills), proses (processes), sikap (attitudes), serta metakognisi (metacognition) dan pemecahan masalah. Pembelajaran matematika di Jepang lebih menekankan pada pemecahan masalah, artinya menjadikan pemecahan masalah sebagai dasar pembelajaran matematika di kelas. Selain itu, pendekatan yang digunakan dalam pembelajaran matematika adalah open-ended, problem solving, dan discovery. Guru-guru Jepang menggunakan 3 prinsip mengajar, yaitu: (a) tanoshii jugyou (kelas harus menyenangkan), (b) wakaru ko (anak harus mengerti), dan (c) dekiru ko (anak harus bisa). Berbeda dengan pembelajaran yang terjadi di Indonesia lebih bersifat abstrak, dan guru lebih menekankan pada ketercapaian kompetensi siswa baik secara individual maupun klasikal serta berorientasi pada learning outcomes. 


\section{REKOMENDASI}

Untuk pengembangan kurikulum dan pembelajaran matematika di Indonesia, perlu kiranya Indonesia sebagai negara berkembang mengadopsi pola pengembangan kurikulum dan pembelajaran matematika yang ada di Jepang. Di samping itu, perlu dilaksanakan pembelajaran matematika sesuai dengan teori-teori pembelajaran matematika terkini dan bergantungan pada 5 (lima) komponen yang saling terkait. Proses pengembangan kurikulum harus diikuti dengan pengembangan perangkat pembelajaran (silabus, RPP, media, penilaian) pada umumnya dan lebih khusus pada mata pelajaran matematika yang sesuai dengan prinsip pelaksanaan kurikulum. Proses pembelajaran matematika pada pendidikan Dasar dan Menengah, guru perlu memberi kesempatan yang lebih luas kepada siswa, hal ini ternyata merupakan kunci utama sehingga siswa mampu dan mau mengemukakan gagasan matematika dan juga memungkinkan siswa untuk menemukan sesuatu yang sama sekali baru. Dengan kata lain, kalau kita selalu memberikan kesempatan kepada siswa untuk berkreasi niscaya siswa akan dapat menemukannya, sehingga pada gilirannya kelak pembelajaran matematika bukan lagi bersifat 'menyuapi' siswa, melainkan siswa sendiri yang akan 'mengkonstruksi' pengetahuan matematika. Sementara itu, untuk proses perkuliahan perlu melibatkan guru, kepala sekolah, dan pengawas. Hal ini dimungkinkan agar di dalam proses perkuliahan, para mahasiswa dapat belajar bersamasama dengan para guru, kepala sekolah, dan pengawas tentang inovasi dalam pembelajaran matematika. Dengan cara begitu, praktik pembelajaran yang terbaru bisa segera diketahui oleh para guru, kepala sekolah, dan pengawas sehingga ketika para lulusan calon guru matematika ingin mengenalkan suatu inovasi terbaru dalam pembelajaran matematika, sekolah akan dengan mudah menyambut ide tersebut dengan baik.

\section{REFERENSI}

Adeluna Chibi. (2014). Pendidikan di Jepang. Diperoleh dari http://japanlunatic.do.am/index/pendidikan_di_jepang/0-296. Diakses, (2015, November 17).

Arifin, S. (2012). Konsep dan Model Pengembangan Kurikulum. Bandung: PT Remaja Rosdakarya.

Brady, Laurie, \& Kennedy, Kerry. (2007). Curriculum Construction. Frenchs Forest, NSW: Pearson, Prentice Hall. 
De Lange. (2000). No Change Without Problems. CD-Rom of the RME materials, produced for the ICME9 Congress in Japan, July 2000.

Djauhari, M. (2001). Arah Pengembangan Kurikulum Bidang MIPA. Makalah disajikan pada Pembukaan Lokakarya Kurikulum Bidang MIPA, Universitas Gajah Mada.

Djojonegoro W. (1995). Opening remark: Minister of Education and Culture Republic of Indonesia at the International Seminar on Science and Mathematics Education. In the Proceeding of International Seminar on Science and Mathematics Education (comparative Study Between Indonesia and Japan) Jakarta dan Bandung (pp.32-39). July, 3-7: JICA-IKIP Bandung.

Hamalik, O. (2001). Landasan Manajemen Pengembangan Kurikulum. Bahan Kajian Matrikulasi Program (S2 \& S3). Pengembangan Kurikulum UPI.

Hara, K. (2007). Gakkō kyōikukateiron. Tokyo: Gakkobunsy

Hudojo H, (2005) Pengembangan Kurikulum dan Pembelajaran Matematika. UM PressUniversitas Negeri Malang

Ibrahim, R. (2005). Pengembangan Kurikulum Program Studi di Perguruan Tinggi: Penekanan Khusus Pada LPTK. Makalah pada Lokakarya Nasional Pengembangan Kurikulum Inti. UPI. Bandung.

Jepang: Sistem Pendidikan dan perbandingan dengan Indonesia. Part 2. Diperoleh dari http://mylawliet.multiply.com/journal. (2015, November 4).

Jihad, A. (2008). Pengembangan Kurikulum Matematika. Bandung. PT Multi Pressindo.

Leder G. (1992). Mathematics and Gender: Changing Perspective. In D.A.Grouws (Ed.), Handbook of Research on Mathematics Teaching and Learning (pp.597-622). New York: Macmillan Publishing Company.

Muliyardi. (2010). Pengembangan Model Pembelajaran Matematika Menggunakan Komik di Kelas I SD (Disertasi Tidak Diterbitkan). Surabaya: Universitas Negeri Surabaya Program Studi Pendidikan Matematika. Diperoleh dari http://indosdm.com. (2015, Agustus).

Mulyono, Abdurrahman. (2003). Pendidikan Bagi Anak Berkesulitan Belajar. Jakarta: Rineka Cipta.

NIER, (1999). An International Comparative Study of School Curriculum. Tokyo. Jepang Nippon Housou Kyoukai (2013) Mengajar Matematika Ala Jepang: Metode mengajar yang Menyenangkan. 
Pangisyarwi. (2015) Comparative Sistem Pendidikan Jepang dengan Indonesia. Diperoleh dari http://www.pangissyarwi.com/index. (2015, November 4).

Ramli, Murni. (2009). Konsep Pembahasan Kurikulum di Jepang. Diperoleh dari http://indosdm.com. (2015, Oktober 22).

Senk SL, DR Thompson. (2003). School Mathematics Curricula: recommendations and Issues. In S.L.Senk \& D.R. Thompson (Eds.), Standard-Based School Mathematics Curricula: What Are They? And What Do Students Learn (pp.3-27). Lawrence Erlbaum Associated: New Jersey.

Stevenson HW, R Nerison-Low. (2002). To Sum it Up: Case Studies of Education in Germany, Japan and the United States. Washington D.C: Office of Educational Research and Improvement, Department of Education.

Stigler JW, HW Stevenson. (1991). How Asian Teachers Polish Each Lesson to Perfection. American Educator: The Professional Journal of the American Federation of Teachers, 15(1), 12-20,43-47.

Suherman, Erman dkk. 2003. Strategi Pembelajaran Matematika Kontemporer. Bandung: UPI.

Sukmadinata,N.S. (1997). Pengembangan Kurikulum Teori dan Praktek. Bandung: PT Remaja Rosdakarya.

Tanti Js. (2012). Kurikulum Matematika di Jepang. Diperoleh dari http://catatantanti.blogspot.com/2012/12/kurikulum_matematika_di_jepang.html. (2015, November 17).

Turmudi. (2008). Taktik dan Strategi Pembelajaran Matematika (Berparadigma Exploratif dan Investigatif). Jakarta: Lauser Cita Pustaka.

Watanabe, A. and Edwin L. Herr. (1993). “Career Development Issues Among Japanese Work Groups.” Journal of Career Development, Vol. 20, pp 61-72.

Wulandari Rini (2014). Makalah Perbandingan Pendidikan di Indonesia, Finlandia, dan Jepang. Diperoleh dari http://academia.edu/7373047/makalah_perbandingan_pendidikan_di_indonesia_fin landia. 